watchwords are diversity, inclusivity,

Multiculturalism in Canada: ifies these terms, and the theoretical Constructing a Model Multiculture arguments behind them, which define with Multicultural Values, Hugh the ultimate goals of Canada's (and not Donald Forbes, Palgrave, 2019, 319 pp., $\quad$ only Canada's) multicultural policies $\$ 35.83$ hardcover.

\title{
Multiculturalism: Democracy by the Experts
}

\author{
Timothy W. Burns
}

The title of this volume may lead one to expect a mere case study. In fact, it is Tocquevillian, announcing a penetrating reflection on a new regime with world-wide ambitions. Forbes aims to show "that a detached examination of the values associated with multiculturalism in Canada can shed a clear light on its nature as a political program or project." The new regime or society that he examines aims to be a respectful "multiculture," one that will "recognize and celebrate every legitimate culture and identity," yet will be, in a contradiction that lies at the heart of the project, a multiculture of "substantial but carefully limited Canadian diversity.” Its for them. He finds his way beyond the "veil of words"-often of bright, welcoming, inflated words-to what multiculturalism actually is.

\section{Pierre Trudeau's Multicultural}

\section{Initiative}

With the gimlet eye of a Tocqueville, Forbes observes multiculturalism in statu nascendi, in order to glean the moral and political significance of the new kind of society emerging on the world scene, in its first full national manifestation. As Tocqueville did not slight the historical development of equality in America, and its political establishment in the American Founding, so Forbes takes us through the decisive appearance, in Pierre Trudeau's 1971 political establishment, of multiculturalism as the best means of accommodating French Canada. Americans may be surprised to learn that multiculturalism, as a political force, begins with Trudeau. And upon learning this they may be inclined, 
as are some Canadians, cynically to attribute its emergence to politics in the low sense. To his credit, Forbes takes account of, and is sometimes assisted by, multiculturalism's wary critics, but he proceeds neither with cynicism about the allegedly low political motives of Trudeau's efforts to bind Quebec to Canada, nor with a misguided fear of its destructiveness. He instead explains the original high purpose conveyed by proponents like Trudeau, and bores into its meaning to see their ultimate purpose: the elimination of the nation state, and its replacement by a novel form of thinking and of political practice.

We therefore learn that while multiculturalism grew almost imperceptibly out of the classic liberal democratic principles and the historical experiences of Canada, its proponents-including Vincent Massey, Roy A. Matthews, and Senator Paul Yuzyk-had in mind, and have produced, nothing less than regime change. Of particular importance in this account is Trudeau's attempt to combat what he saw as the bellicose and intolerant nationalist sentiments informing mono-national states, on one hand, and the alienation or sense of homelessness produced by modern, mass industrial, and commercial society, on the other. Trudeau sought, Forbes argues, to address both of these perceived problems through novel, government support of multiple, deracinated, residual, liberal, secular, tolerant forms of pre-liberal "cultures," that is, through polyethnicity. He did so in an effort to produce a pluralist model for tomorrow's world of "enlightened humanism," one with a rational consensus concerning cultural rather than individual integration. Multiculturalism was to be Canada's leading contribution to a future "universalist order."

The resultant changed reality of Canada's modern political life affords Forbes the opportunity to employ much more irony than Tocqueville. While Forbes's account is often wryly amusing, it is ever guided by serious reflection about the human good and of judgments about the human good that find multiculturalism nightmarish. Aware of what classic liberalism and its virtues were, Forbes permits us to see the profound differences between them and multiculturalism, even as its proponents call themselves liberals and democrats.

With his description of democracy in America, Tocqueville presented to his compatriots and to the world a regime that the hand of History, or perhaps Providence, had dealt to the world, but one in dire need of remedies from a decline into soft despotism. But the very goal of the new 
regime of multiculturalism, Forbes gently, quietly shows us, is despotic. It is both anti-democratic and anti-liberal, in ways that Americans should find alarming.

From the outset, Forbes finds, there was an anti-democratic tendency to the move to assert equality of cultural groups, a move that was aimed against the majority culture's alleged oppression. The tendency is visible both in anti-majoritarian courts and in "new agencies with broad discretionary powers to compel or forbid or conciliate,"-agencies with "flexible rules," that is, unconstrained by due process of law. Trudeau's multiculturalism was conceived as a stepping stone to a progressive, rational society and was to rely "on the delegation of legislative power to various well trained officials and quasi-judicial tribunals" and on a growing bureaucracy of experts who would make the necessary shifts in burdens to achieve the correct amalgamation of the right kind of cultures. At the same time, he sought to infuse the traditional cultures with the correct, progressive political culture.

The Trudeauean move to multiculturalism was also, Forbes shows us, anti-liberal. Achieving the desired proportionate equality of different cultural groups required the abandonment of the crucial liberal distinction between the state and society, and also (and this will come as no surprise to "Bernie Bros") of the socialist attention to the inequalities between rich and poor individuals, on the ground that the official liberal equality of individual rights masks persistent inequalities of outcomes by historically disadvantaged "cultures" and their members. "Equity equality" requires affirmative action by governmental bodies to produce proportionate equality of targeted, protected cultural identity group outcomes in employment, memberships, awards, etc. It thus sharpens and brightens the lines that separate cultures in its effort to recognize, preserve, and protect minority cultures and thereby ensure cultural equality and cultural freedom. Such "inclusivity," Forbes notes, inevitably involves exclusivityrestrictions on "insensitive" speech and expression and other restrictions on individual choice and judgmentgenerating resentment and hostility from traditional liberal citizens instead of the desired multicultural happiness.

\section{Post-Facto Theoreticians of \\ Trudeau's Multiculturalism}

But did no one in Canada stand up in defense of liberal democratic principles in the face of Trudeau's onslaught? Anyone who has spent 
time in Canada observing its political life will not be surprised to learn that the answer is: not really. What instead took place was an effort to lend a theoretical clarification to what Trudeau had set in motion. The chief name here is Will Kymlicka, as Forbes explains, whose theorizing invites his readers to re-introduce into political life a "positive freedom," or freedom to choose what is good rather than what is bad, to be achieved through the accommodation of various cultures, especially the hitherto oppressed ones-cultures in which those notions of good (and the obligations that they entail) are embedded and sustained. As Forbes makes clear, this effort resurrects the specter of a government compelling its citizens to pursue these notions of the good-the very thing that classic liberal regimes were designed to avoid.

As it is anti-liberal, Kymlicka's multiculturalism is also anti-democratic. It intends to re-educate the majority, but like Trudeau, Kymlicka and his numerous students in Canadian public life hope that the exotic cultures brought by the "other" to Canada through increased immigration will in turn become, like the majority culture, deracinated, tolerant, progressive versions of their former selves. (For the same reason, the multiculturalists direct their ire at the majority Christian culture when, and because, it has more or less successfully resisted secularization and liberalization.) And since, in the view of these bureaucrats, majoritarian democratic politics bids to retain its relative strength, every effort must be made to defeat it by means of the non-elective bureaucratic state and the courts. Hence, in the bureaucratic opponents of majoritarianism, "one can see the hope that expertly guided deliberation (in law courts, tribunals, and other offices of the bureaucracy) may one day replace more openly political debate in representative assemblies and during election campaigns."

Equally important in support of Trudeau's multiculturalism was Charles Taylor, and his case for a politics of "recognition." In examining his work, Forbes shows that Taylor's demand for "recognition" of groups produces the same crumbling of classical liberalism that one sees in Kymlicka's scheme. Classic liberals adhere to inalienable equal rights of persons, but Taylor argues for inalienable demands for recognition of the equal value of all cultures, an "equal recognition of what everyone, even those in metaphorical comas, have actually made of their potential," as Forbes puts it. Taylor is aware, Forbes notes, that our moral judgments of 
such cultural groups cannot be compelled, nor will our judgments yield equal recognition to all. (We may, for example, judge the stoning to death of apostates to be abhorrent.) Yet Taylor demands the survival of all distinct cultures and "identities" over and against the culturally homogenizing tendency of liberal democracy. $\mathrm{He}$ would therefore have individuals feel obliged, against their own judgments, to grant to cultures and identities more recognition, accommodation, and more "freedom to violate the equal individual rights of other individuals... than they can be given under a liberal democratic regime of equal individual rights as usually understood.”

Along with recognition, Taylor's other prong of multiculturalism is "authenticity," the difficult heeding of the call of one's inner self, or what was once called the conscience, "God, the Law, or the Idea of the Good.” Yet as Forbes brings out, Taylor is in truth attempting to put an end to this moral struggle, identifying authenticity as the free (groundless?), conscious adoption, as one's own, of all of one's traditional culture's highest mores and opinions. The multiculturalist Taylor counsels recognition of and accommodation to only recognizable others-to those, that is, and only those, who have transformed themselves, through dialectical negotiation of their "identities" with others, and thereby brought their authentic selves into line with or have "retrieved" the highest (that is, most progressive) aspirations of their culture. One must stand tall for what one is-until one becomes something else-and permit the experts sitting on human rights commissions and intercultural commissions delicately to combat, through investigations, re-education, and penalties, any racism, "ethnism," and hatred that may continue to lurk in one's authentic self. It is by means of such inauthenticity, posing as authenticity, that societies like Quebec hope to achieve the "smooth bureaucratic blending of clashing cultures" that will "serve economic efficiency, social justice, dependable pensions, the rule of law, and world peace," Forbes explains.

\section{“Openness"}

As important as Kymlicka's and Taylor's Orwellian cases for the promotion of oppressed cultures, recognition, and authenticity have been for the advance of multiculturalism in Canada, its greatest "mega-value," Forbes finds, is a devotion to "openness." Forbes himself follows Allan Bloom in suggesting that genuine (if rare) openness is to be open to reasoned and rational arguments of others. But this is a quite different 
kind of openness, Forbes reminds us, from what is at work in multiculturalists. Their openness is instead a blend of, on one hand, the openness found in Karl Popper's open society, with its reliance on science and "piecemeal social engineering," and, on the other, the aspirational "openness" of Henri Bergson. The latter is based on what Bergson considered the non-scientific, mystic or metaphysical "brotherhood of man," one that is "fundamentally an attitude of receptivity to the prompting of an intuitive or even mystical sense of universal connectedness and obligations." Bergsonian openness has, that is, a religious basis, but of a new sort, one that has been prepared by the "demystification" of traditional societies achieved through modern science and technology. The creative, "myth-making” function of divinized human beings can enhance life, at least after a "thoroughgoing spiritual reform" away from the "closed" religious dogmas of the past.

\section{The Results}

What, then, will the postmodern constitutionalism of the multiculturalists, informed as it is by the thought of Trudeau, Kymlicka, Taylor, Popper, and the neo-religiously inclined Bergson, finally yield? In the two chapters (8 and 9) that precede his conclusion, Forbes treats us to what one is tempted to call a series of Swiftian warnings of what the future holds. We glimpse a future governed by experts who carefully manage "the realistic reforms that could promote the ideal of global citizenship based on multicultural values" and guard against threats to "authentic" openness.

The experts control the economy, education, the media, awards, para-judicial commissions, and political life; they operate with steadiness, careful calibration, and discretion or secretiveness, but with the militant zeal of youthful cultural revolutionaries, simultaneously naïve and ruthless in their destruction of any and all reminders of "backward" traditions, of serious religious faith, and of outcomes-political, economic, and social-that are not ethnically balanced. They deftly use police and other security services, equipped with the latest surveillance technology, and with the therapeutic resources of re-education and sensitivity training, to achieve their ends. The resulting portrait has all the droll humor of a series of Soviet-era Russian jokes. After the completion of their work, "the truth of multiculturalism, all will ... recognize, with relief, is Canadian and global monoculturalism."

That an impoverished and despotic monoculturalism, albeit one that a particular nation proudly and 
self-contradictorily presents as its unique contribution to a future universal human life, is the inevitable outcome of multiculturalism, should give Americans pause. Forbes's book clarifies the problematic arguments guiding this new monoculturalism in Canada and, as we know, have come to dominate American colleges and universities. Americans can be grateful that one Canadian, at least-a contemporary Tocquevillian-has sent out a clear and convincing warning about what now threatens our own contemporary intellectual and political life. 